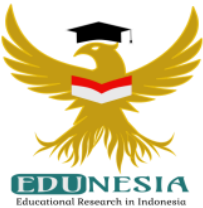

\title{
Assessment Online Learning at Elementary School
}

\author{
Zaitun'; Rochmiyati²; ${ }^{1}$ Pargito $^{3}$ \\ 1,2,3 Department of Primary Education, Universitas Lampung, Indonesia \\ ${ }^{1}$ Corresponding Email: olivenajam84@gmail.com, Phone Number: 0896 xxxx xxxx
}

\section{Article History:}

Received: July 17, 2021

Revised: August 12, 2021

Accepted: August 24, 2021

Online First: August 28, 2021

\section{Keywords:}

Assessment,

Leraning,

Online.

\section{Kata Kunci:}

Penilaian,

Pembelajaran,

Online.

\section{How to cite: \\ Zaitun, Z., Rochmiyati, R., \& Pargito, P. (2021). Assessment Online Learning at Elementary School. Edunesia: Jurnal Ilmiah Pendidikan, 2 (3): 663-667.}

This is an open access article under the $C C$-BY-NC-ND license
Abstract: This study aims to determine the assessment model for online-based elementary school teachers during the Covid19 pandemic. This research was carried out at SDN 2, Palas District, South Lampung Regency. The research method used in this study is a qualitative research method with a descriptive study approach. The data collection techniques used are through questionnaires and interviews. The results showed that the online assessment in elementary schools during the Covid19 pandemic was carried out through: assignments, daily exercises (oral tests), written tests and portfolios. From the various types of assessments carried out, it turns out that there are several obstacles, from the results of interviews that have been conducted, the obstacles experienced in online assessments are skills and attitude assessments to overcome the obstacles regarding online assessment, it still needs to be developed again, namely self-assessment and parental assessment to help solve problems regarding attitude and skill assessment.

Abstrak: Penelitian ini bertujuan untuk mengetahui model penilaian pada guru sekolah dasar berbasis daring pada masa pandemi Covid - 19. Penelitian ini dilaksanakan di SDN 2 Bangunan, Kecamatan Palas, Kabupaten Lampung Selatan. Adapun metode penelitian yang digunakan dalam penelitian ini ialah metode penelitian kualitatif dengan pendekatan studi deskriptif. Adapun teknik pengumpulan data yang digunakan ialah melalui angket dan wawancara. Hasil penelitian menunjukkan bahwa penilaian daring di sekolah dasar pada masa pandemic Covid -19 ini dilakukan melalui: tugas, latihan harian (tes lisan), tes tulis dan fortofolio. Dari berbagai jenis penilaian yang dilakukan ternyata terdapat beberapa kendala, dari hasil wawancara yang telah dilakukan, kendala yang dialami dalam penilaian daring yaitu penilaian keterampilan dan sikap. Untuk mengatasi kendala tentang penilaian daring masih perlu dikembangkan lagi penilaian diri sendiri dan penilaian orang tua untuk membantu memecahkan masalah tentang penilaian sikap dan keterampilan. 


\section{A. Introduction}

Corona virus has brought many changes in all aspects of life, both identification of ways of working, interaction, and lifestyle. This has created a new context regarding the social, cultural and educational arrangements that exist in the world that are experiencing the impact of the COVID-19 virus, including in Indonesia (Sahudra et al, 2021). Weaknesses and advantages are seen, both in the global context and in the domestic context, new challenges have emerged that must be faced by society as a whole, especially in the field of education (Manta, 2021). Digital technology is a key component in collective efforts to tackle the challenges of the COVID-19 virus and support new ways of life and activities in this extraordinary period (Mihaela, 2021).

With the emergence of the covid 19 virus, it has become an obstacle for all people in the world and this is also a threat to human health. In the world of education, this is also very impactful. The impact of Covid 19 on the world of education is very large and is felt by various parties, especially for educators, students and also parents. Due to the high level of the pandemic, universities and colleges around the world have been closed down to the elementary school level for an undetermined time (Sari, 2021).

By closing schools or direct learning, the government takes steps so that the learning process is not left behind and students continue to receive the right to education, therefore the next government decision is that the learning process is carried out by Distance Learning (PJJ) or online. Distance learning is implemented not only for the higher education level but also for the basic education level (Samosir, 2020). Online learning is a learning method that uses technology and internet networks starting from the use of Whatsapp, Google Classroom, Zoom or other applications (Kristina, 2020). Some things that can be done during online learning are communicating with each other and discussing online (Anugraha, 2020). Teachers must ensure that learning activities must continue even though students are at home, thus a teacher must design media, models and learning instruments as innovations by utilizing online media (in the network) online (Rohana, 2020).

Online learning is basically a form of transformation of human thinking in communicating and collaborating (Garisson in Cahyaningtyas, 2020). Learning with this model can be done in 3 ways, namely by self-paced independent study, asynchronous interactive, and synchronous interactive (Katto et al in Cahyaningtyas, 2020). In a self-paced independent study, the teacher has prepared material for a certain period of time, including material and evaluation that has been accompanied by an answer key and assessment guidelines. This makes students more independent in determining their own study schedule, but there is no direct interaction between students and teachers. Meanwhile, in asynchronous interactive, students and teachers interact but not directly and not at the same time. Teachers can use email or chat services to share materials or evaluation questions that students can work on within a certain time, and can also ask questions with replies according to the free time students and teachers have. It is different from synchronous interactive, where students and teachers conduct questions and answers and discuss material and evaluation questions at the same time (Cahyaningtyas, 2020).

Online learning requires educators to use various appropriate and supportive assessment or assessment models to be applied (Mayasari \& Kemal, 2020). Several assessment models that can be applied in the distance learning process include online-based assessment, portfolio assessment, and self-assessment (Martin, 2020). As for the assessment or evaluation instrument, it still refers to curriculum 13, so the implementation of the evaluation for these four aspects must be carried out, but the implementation of course 
undergoes modifications, or changes to adapt to the needs, situations and conditions of current online learning (Lubis, 2020).

Based on previous research that has researched and studied a lot of assessment instruments such as "online-based PAI learning evaluation models in MTs. Usman Syarif Medan during the covid-19 pandemic," development of an assessment instrument for PAI lessons (Lubis, 2020). "Training on the preparation of HOTS-based questions and their application in online learning in elementary schools." (Cahyaningtiyas, 2020). "Obstacles, solutions and hopes: online learning during the COVID-19 pandemic by primary school teachers." (Anugrahana, 2020). "Online learning model after the covid-19 pandemic." (Rohana, 2020). From several studies that develop online-based assessment instruments, there are still many carried out at the secondary school level and for elementary schools, there is still not much done. Because online learning during this pandemic is an option that must be implemented throughout the country, and of course the assessment instrument for elementary schools has also changed, research on online learning assessment in elementary schools is very necessary and this research is very good to help educators in primary schools.

\section{B. Method}

Method used in this research is a qualitative research method with a descriptive study approach. With the aim of knowing online-based assessments of elementary school teachers during the COVID-19 pandemic. The subjects in this study were teachers of grades 1-6 and subject teachers at SDN 2 Bangunan which is located at Jl. Cita Jaya, Building Village, Kec. Palas, Kab. South Lampung. with the research instrument used in the form of an open questionnaire given to teachers through the google form application, and interviews conducted through the google meet application.

In addition, researchers also obtained data from the results of literature studies from various literature books, journals, scientific works, as well as other documents that examine online learning assessment and evaluation, both in general and specifically related to distance learning assessment and evaluation (Ahmad, 2020).

\section{Result and Discussion}

Based on the initial research that has been carried out, the results obtained from open questionnaires and interviews given to the teachers of SDN 2 Gedung. The questionnaire was given through theapplication Google Form and interviews were conducted through theapplication. The Google Meet results showed that from 6 class teachers and 3 subject teachers answered all of them tried to conduct online assessments during the Covid-19 pandemic in accordance with government recommendations or still following curriculum 13, namely 4 core competencies.

The online assessment in elementary schools during the Covid-19 pandemic was carried out through: assignments, daily exercises (oral tests), written tests and portfolios. From the various types of assessments carried out, it turns out that there are several obstacles, from the results of interviews that have been conducted, the obstacles experienced in online assessments are skills and attitude assessments, as well as assessments by PJOK subject teachers also experience difficulties.

From several online assessments that have been carried out by teachers at SDN 2 Banguanan, it still needs to be developed further, namely self-assessment and parental assessment to help solve problems regarding attitude and skill assessment, because self- 
assessment can assess honesty, responsibility and also skills. While the assessment of parents plays an important role in online learning, this is because students are 24 hours with their parents.

From the results of research (Wulandari, 2020). Regarding the analysis of "online" learning for elementary school teachers in the Covid-19 era, explaining that the change from face-to-face learning to online learning provides various kinds of obstacles in education, especially for teachers who are the spearheads in the implementation of learning. Some of the problems faced by teachers in online-based learning include those related to learning applications, internet connection networks, management, assessment and supervision of learning.

Teachers should provide simple, clear, and precise instructions about what to do, how to do it, and where students should turn in their work. Activities should be determined with the objectives in mind and arranged sequentially in tasks that reflect life situations to get students' interest and keep them motivated.

From the results of research (Ahmad, 2020). Alternative assessment in distance learning in amergencies spread of corona virus disease (Covid-19) in Indonesia. Self Assessment is an assessment method that provides opportunities for students to take responsibility for their own learning. Therefore, educators can start the self-assessment process by providing opportunities for students to validate their own thinking.

\section{Conclusion}

There has been a change in learning during the Covid-19 pandemic, one of which is the learning assessment model. If during the school period face-to-face all learning models and all assessment models can be used because nothing is a barrier, now they are limited by space and distance which are considered in doing everything. If in the past the assessment could be done in person, now the assessment cannot be done directly but must be done online. The results of the research at SDN 2 Gedung showed that there were several modified assessment models as an alternative during the Covid-19 pandemic. Online assessment in elementary schools during the Covid-19 pandemic was carried out through: assignments, daily exercises (oral tests), written tests and portfolio.

There are several obstacles experienced in online assessment, namely the assessment of skills and attitudes. To overcome the obstacles regarding online assessment, it still needs to be developed again, namely self-assessment and parental assessment to help solve problems regarding attitude and skill assessment, because self-assessment can assess honesty, responsibility and skills. While the assessment of parents plays an important role in online learning, this is because students are 24 hours with their parents. provision of assessment reports both cognitive, affective, and psychomotor are also delivered online.

\section{References}

Ahmad, I.F. (2020). Alternative assessment in distance learning in amergencies spread of corona virus disease ( covid -19) in Indonesia. Jurnal Pedagogik.

Anugrahana, A. (2020). Hambatan, solusi dan harapan: pembelajaran daring selama masa pandemic covid-19 oleh guru sekolah dasar. Scholaria: Jurnal Pendidikan dan Kebudayaan. 
Cahyaningtiyas, A.P. (2020). Pelatihan penyusunan soal-soal berbasis HOTS dan aplikasinya dalam pembelajaran daring di sekolah dasar. Indonesian Journal of Comonity Services.

Kristina, M. (2020). Model pelaksanaan pembelajaran daring pada masa pandemic covid 19 di provinsi Lampung. Jurnal Idaarah.

Lubis, R.R. (2020). Model evaluasi pembelajaran PAI berbasis daring di MTs. Usman Syarif Medan selama pandemic covid -19. el-Buhuth.

Manta, O.C. (2021). Online learning of socio-emotional behaviors in primary education during the COVID 19 pandemic. Case study. Technium Social Sciences Journal.

Martin, K. (2020). Pengembangan Assessment dalam Pembelajaran Daring untuk Mata Kuliah Pengukuran dan Instrumen. Jpte ( Jurnal Pendidikan Teknik Elektro).

Mayasari, Ika, L., \& Kemal, I. (2020). The Role Of Teachers In Implementing Distance Learning In The Middle Of The Covid-19 Plague. Sytematics Review In Pharmacy, 11 (12), pp. 1553-1557. https://www.sysrevpharm.org/articles/the-role-of-teachersin-implementing-distance-learning-in-the-middle-of-the-covid19-plague.pdf

Mihaela, R. (2021). Student perception of online education supported in the Covid-19 period. Technium Social Sciences Journal.

Rohana, S. (2020). Model pembelajaran daring pasca pandemic covid -19. At-Ta'dib: Jurnal Ilmiah Prodi Pendidikan Agama Islam.

Sahudra., Tengku, M., Taher, A., \& Kemal, I. (2021). E-Learning Development Management With The Schoology Improving Geographic Learning Litearation. Journal of Education Technology, 5 (1), pp. 70-75. http:/ / dx.doi.org/10.23887/jet.v5i1.33631

Samosir, A. (2021). Dampak pembelajaran daring terhadap perilaku Bahasa dan sosial peserta didik di SMK IT Nurul Ilmi. Jurnal Akrab Juara.

Sari, R.P. (2021). Dampak pembelajaran daring bagi siswa sekolah dasar selama covid-19. Prima Magistra: Jurnal Ilmiah Kependidikan.

Wulandari, M.A. (2020). Analisis pembelajaran "daring" pada guru sekolah dasar di era covid-19. Jurnal Ilmiah UPT P2M STKIP Siliwang. 